\title{
Phosphatidylserine IgM Antibody Unit
}

National Cancer Institute

\section{Source}

National Cancer Institute. Phosphatidylserine IgM Antibody Unit. NCI Thesaurus. Code C161496.

A unit for semiquantitative measurement of $\lg M$ autoantibodies to proteins associated with phosphatidylserine evaluated ag ainst an established reference standard. 